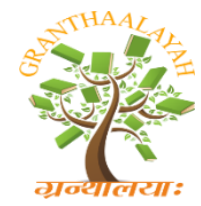

INTERNATIONAL JOURNAL OF RESEARCH GRANTHAALAYAH A knowledge Repository

Management

\title{
INTENTIONS TOWARDS SOCIAL ENTREPRENEURSHIP AMONG UNIVERSITY STUDENTS IN INDIA
}

\author{
Dr. Sarada Chengalvala ${ }^{1}$, Dr. Satyanarayana Rentala ${ }^{2}$ \\ Associate Professor in Commerce, VSR Government Degree and PG College, Movva (Krishna \\ District), Andhra Pradesh - 521 135, India \\ Program Manager - South Zone, Piramal Foundation for Education Leadership, A-56, Panchseel \\ Enclave, New Delhi - 110 017, India
} 2

DOI: https://doi.org/10.29121/granthaalayah.v5.i6.2017.2049.

\begin{abstract}
Social entrepreneurship is the ability to be an agent of change for various economic, environmental, social and political issues at local and global levels. It is believed that exposure of youth to social entrepreneurial theories and practice in institutes of higher education can impact this change. The students in various universities armed with knowledge and skills that they gained, with the support of entrepreneurial culture and environment while in campus may help them to choose social entrepreneurship as a career option after their formal education. In this backdrop, this research aims to identify the levels of entrepreneurial intentions and social entrepreneurship among University students. A sample of 150 university students across the country was included in the research. Factor analysis was used to identify factors that influence social entrepreneurship intentions. Five factors which influence social entrepreneurship intentions were identified - social entrepreneurship interest, entrepreneurial attitude, proactive personality, entrepreneurship education and perceived behavioral control. Furthermore, correlation analysis was conducted to investigate the relationship amongst social entrepreneurship intentions factors. The results were significant which indicated that there was a positive linear inter-factor association.
\end{abstract}

Keywords: Entrepreneurship; Entrepreneurship Education; Career Intentions; Social Entrepreneurship.

Cite This Article: Dr. Sarada Chengalvala, and Dr. Satyanarayana Rentala. (2017). "INTENTIONS TOWARDS SOCIAL ENTREPRENEURSHIP AMONG UNIVERSITY STUDENTS IN INDIA.” International Journal of Research - Granthaalayah, 5(6), 406-413. https://doi.org/10.29121/granthaalayah.v5.i6.2017.2049. 


\section{Introduction}

Entrepreneurship is the dynamic method of making progressive wealth. The wealth is formed by people who are ready to take the risks in terms of equity, time or give value for a few product or service. Entrepreneurship is the creation of little to medium businesses, plays a significant role in creating wealth for the person, rise in employment opportunities, improving quality of living, and provides platform for innovation, and increase in productivity in any country. Adoption of entrepreneurship among university students has become a significant topic among entrepreneurship researchers. The university is an establishment, wherever students pass on toward next stage of operating life. Right after the graduation, students decide how to go forward with their life. The entrepreneurial initiatives play a key role in developing a country's economic and social wellbeing.

An entrepreneur may be a person who seeks for changes of life and environment around him, and to use the change as a chance to move forward. With sufficient requirement of capital, education and own innovation, intelligence, energetic is changed into a professional business individual.

A social entrepreneur identifies executable solutions to social issues by bringing together innovation and chance. They draw upon wise thinking in each the business and nonprofit worlds and operate altogether varieties of organizations. Over the past 20 years, the social sector has discovered what the business learned long ago, there's nothing as powerful as a replacement plan within the hands of a primary-class entrepreneur.

Social entrepreneurs are covered with their ideas, and providing their lives to ever-changing the direction of their field. They are visionaries, however additionally realists, and area unit ultimately involved with the sensible implementation of their vision specifically else. Social entrepreneurs present easy, graspable, and ethical ideas that have interaction widespread support so as to maximize the quantity of citizens that may rise, seize their plan, and implement it. Social entrepreneurship is that the way of failures with financially sustainable innovations geared toward identifying social problems has emerged.

It's a replacement breed of entrepreneurship that exhibits characteristics of nonprofits, government, and businesses together with applying to social problem-solving traditional; privatesector entrepreneurships target innovation, risk- taking, and large-scale transformation. Dedicated to supply social price, these entrepreneurs establish new processes, services and product, or excusive ways in which of mixing verified observe with innovation to deal with complicated social issues.

In this research, an attempt is made to understand the intentions of university students regarding social entrepreneurship as a future career of choice. Additionally, this research also attempts to understand the challenges perceived to undertake social entrepreneurship as a career choice among university students in India. 


\section{Review of Literature}

A study about the attitudes of the youth in India by Agarwal and Upadhyay (2009) identified family background and educational qualifications as key dimensions of entrepreneurial intentions. The authors suggest that entrepreneurial intentions have long been established as crucial for the process of entrepreneurship since they provide the impetus for entrepreneurial ideas to become manifested.

Ahmed et al (2010) concluded that it is difficult to differentiate entrepreneur from nonentrepreneur on the basis of age, gender or entrepreneurial back ground, as the findings suggest that there is no significant relationship between these variables and intentions to become entrepreneur. But, family background and level of education mattered while intending to become an entrepreneur. Students in senior classes are more inclined towards entrepreneurship because of their higher levels of knowledge and practical exposure with the field and market.

Maalu (2012) analysed the perceptions of public secondary students in Nairobi regarding entrepreneurship as a career. The findings revealed that majority of students in public secondary schools in Nairobi had a positive perception of entrepreneurship as a career. While majority of them indicated that they would want to pursue a career in entrepreneurship after completing school, several factors emerged as possible barriers to their entry into entrepreneurship. Majority of students perceived insufficiency of funds, stiff competition and insufficient knowledge on how to run the business as major challenges.

Lorz (2011) applied the theory of planned behavior to entrepreneurship education. Initial results from the qualitative analysis of the entrepreneurial-trigger events proposed a possible blend of the theory of planned behavior and elements of the entrepreneurial event model. Entrepreneurial trigger-events may represent the tipping point for those students with an already high entrepreneurial intention to turn ideas into reality and become self-employed. Having completed this study, the author believes that entrepreneurship education is still of crucial importance for facilitating entrepreneurship.

Mueller and Neck (2010) suggest that traditional entrepreneurship courses offer the foundational skill set for all entrepreneurial ventures regardless of type. The authors contend that the content in entrepreneurship course does not require repetition in social entrepreneurship classes. Rather, social entrepreneurship classes should focus on the specific issues uncovered in the research such as social impact, aligning personal values and interests with the entrepreneurial behavior and balancing social and economic aspects of business. The personal values and interests category comprises reasons reflecting the belief that with entrepreneurial actions one can act according to personal values, motives, passions, and interests.

Nga and Shamuganathan (2010) found that certain personality traits such as agreeableness, openness and conscientiousness exert an influence on social entrepreneurship dimensions. The implication of how the development of character and social entrepreneurship can be inculcated through student-centred learning and life-long learning had been highlighted in the study. 
A study by Nian et al, (2014) provides an important exploratory analysis for entrepreneurship education. The authors argue that an entrepreneurship education should not only provide theoretical knowledge but also be able to assist the students on establishing an entrepreneurship mind set through developing entrepreneurial skills, behaviours and attitudes. The students should also be trained in entrepreneurial abilities to support them to start their own business venture or engage in entrepreneurship activities. The results show the entrepreneurship education in the higher learning institutions has a positive perception of the students towards entrepreneurship education.

Salamzadeh et al (2013) found that many university students are aware of the concept of entrepreneurship. However the understanding about entrepreneurship was found to be higher among students who have taken entrepreneurship as a course. There was some confusion about social entrepreneurship and only relatively weak awareness of national social entrepreneurs. Conclusions drawn suggest that there is a need to develop social entrepreneurship education in higher education.

Tiwari et al (2017) investigated the career development theory framework using a sample of students from a technological university in India. They found that individual goal setting and commitment towards society has direct implications for the growth of social enterprises. This has implications for training and development right at the young age during school and university level and creating a social entrepreneurial culture in the society to enhance motivation towards social entrepreneurship.

Majority of the authors conclude that social entrepreneurship embodies elements of both traditional business entrepreneurship with its focus on opportunity recognition and exploitation of economic value and social dimensions of social entrepreneurship which emphasise social value creation (Shane \& Venkataraman 2000).

\section{Research Methodology}

The aim of the study was to identify the social entrepreneurship intentions among university students. With the aim of identifying social entrepreneurship intentions among university students, the target population for the study comprised of some specific university students. The sample was drawn from varies universities in India. The sample consisted of 150 students who were attending final year of their course. The process of data collection used in this study included conducting a literature study and administering a questionnaire. A literature study on social entrepreneurship intention was conducted in order to identify factors that determine social entrepreneurship intentions.

The questionnaire consisted of three sections. The first section captured the demographic profile of the respondents. The second and third sections contained questions regarding social entrepreneurship intentions and perceived constraints to start social enterprises. Using various items in the questionnaire, a total of five factors were identified. They are social entrepreneurial interest (9 items), entrepreneurial attitude (8 items), proactive personality (6 items), entrepreneurship education (5 items) and perceived behavioral control ( 7 items). 


\section{Analysis and Discussion}

In this section, the results of the analysis were presented. Firstly, demographic profile of the respondents is presented. This is followed by other analyses.

\begin{tabular}{|l|l|l|l|}
\hline \multicolumn{5}{|c|}{ Table 1: Demographic Profile of Respondents } \\
\hline Demographic Variable & Parameters & Frequency & Percentage \\
\hline Gender & Male & 92 & 61 \\
\hline & Female & 58 & 39 \\
\hline & Total & $\mathbf{1 5 0}$ & $\mathbf{1 0 0}$ \\
\hline Age & Less than 20 years & 9 & 6 \\
\hline & 20-25 years & 96 & 64 \\
\hline & $25-30$ years & 45 & 30 \\
\hline & $30-35$ years & 0 & 0 \\
\hline & Total & $\mathbf{1 5 0}$ & $\mathbf{1 0 0}$ \\
\hline Educational Status & Graduation & 66 & 44 \\
\hline & Post-Graduation & 72 & 48 \\
\hline & Ph.D. & 12 & 8 \\
\hline & Total & $\mathbf{1 5 0}$ & $\mathbf{1 0 0}$ \\
\hline Field of Study & Engineering & 56 & 37 \\
\hline & Commerce & 8 & 5 \\
\hline & Management & 60 & 40 \\
\hline & Science & 4 & 3 \\
\hline & Others & 22 & 15 \\
\hline & Total & $\mathbf{1 5 0}$ & $\mathbf{1 0 0}$ \\
\hline
\end{tabular}

Table 1 presents a summary of the demographic profile of the respondents. It can be noted that nearly 60 per cent of the respondents are male while 40 per cent are female. This is in tune with the general diversity trends among Indian institutions. Majority of the respondents are either graduate students or post-graduate students and fall into the age group of 20-25 years. It can also be noted that majority of the respondents are pursuing either engineering or management reflecting the present preferences of Indian students.

Table 2 gives an account of the descriptive statistics for the five factors included in the research. It can be observed that having an interest in social entrepreneurship is the most important factor that determines the intentions of university students towards social entrepreneurship in India. This is followed by other factors like proactive personality and exposure to academic courses in entrepreneurship education. 


\begin{tabular}{|l|l|l|l|}
\hline \multicolumn{4}{|c|}{ Table 2: Descriptive Statistics for Various Factors } \\
\hline N=110 & Minimum & Maximum & Mean \\
\hline Social Entrepreneurship Interest & 2 & 5 & 3.96 \\
\hline Entrepreneurial Attitude & 2 & 5 & 3.55 \\
\hline Proactive Personality & 2 & 5 & 3.91 \\
\hline Entrepreneurship Education & 3 & 5 & 3.68 \\
\hline Perceived Behavioural Control & 2 & 5 & 3.57 \\
\hline
\end{tabular}

Table 3 presents the results of the reliability test. Reliability is defined as the extent to which a measuring instrument consistently reflects the variable that it is measuring. In research literature, Cronbach ${ }^{\text {ee }}$ alpha is the most common measure of scale reliability .Generally, acceptable Cronbach ${ }^{\text {ee }}$ alpha values range from 0.7 and above. Values below 0.7 indicate an unreliable scale. The overall Cronbach ${ }^{\text {ee }}$ s alpha coefficient for this study was 0.867 , which indicated good internal consistency of social entrepreneurship intentions scale used in the study. The Cronbach"s alpha values for the five individual factors ranged from 0.5 to 0.9 . Alpha values for Factors 1 to 3 were above the acceptable value of 0.7 and, therefore, indicated good internal consistency. Alpha values for Factors 4 and 5 were marginally acceptable.

\begin{tabular}{|l|l|l|}
\hline \multicolumn{2}{|c|}{ Table 3: Reliability Test } \\
\hline Factor & Cronbach's alpha & Number of items \\
\hline Social entrepreneurial interest & 0.835 & 11 \\
\hline Entrepreneurial attitude & 0.762 & 10 \\
\hline Pro-active personality & 0.71 & 8 \\
\hline Entrepreneurship education & 0.604 & 5 \\
\hline Perceived behavioral control & 0.527 & 7 \\
\hline
\end{tabular}

Table 4 presents the results of the correlation analysis. The table shows that social entrepreneurial interests showed a moderate relationship with proactive personality $(\mathrm{r}=$ $0.479, \mathrm{p}<0.01)$, entrepreneurial attitude $(\mathrm{r}=0.451 ; \mathrm{p}<0.01)$, perceived behavioral control $(\mathrm{r}=0.439 \mathrm{p}<0.01)$ and entrepreneurship education $(\mathrm{r}=0.335 \mathrm{p}<0.01)$.

\begin{tabular}{|l|l|l|l|l|l|}
\hline \multicolumn{7}{|c|}{ Table 4: Correlation Matrix for Various Factors } \\
\hline & SEI & EA & PP & EE & PBC \\
\hline Social Entrepreneurship Interest (SEI) & 1 & & & & \\
\hline Entrepreneurial Attitude (EA) & $.451^{* *}$ & 1 & & & \\
\hline Proactive Personality (PP) & $.479 * *$ & $.296^{* *}$ & 1 & & \\
\hline Entrepreneurship Education (EE) & $.335^{* *}$ & $.674 * *$ & $.237^{*}$ & 1 & \\
\hline Perceived Behavioural Control (PBC) & $.439 * *$ & 0.081 & $.519 * *$ & 0.11 & 1 \\
\hline$* *$ Correlation is significant at the 0.01 & level & (2-tailed). \\
$*$. Correlation is significant at the 0.05 level (2-tailed).
\end{tabular}

Entrepreneurial attitude had a strong relationship with entrepreneurship education $(\mathrm{r}=0.674$ $\mathrm{p}<0.01)$ and weak relationship with Proactive personality $(\mathrm{r}=0.296, \mathrm{p}<0.01)$. Proactive 
personality also had a weak correlation with entrepreneurship education $(r=0.237, p<0.01)$ and a strong relationship with Perceived behavioral control $(\mathrm{r}=0.519, \mathrm{p}<0.01)$. Entrepreneurship education had a weak relationship with Perceived behavioral control $(\mathrm{r}=0.114)$.

Taken together, these findings imply that students with the intentions to start to a business with a social mission are those with the entrepreneurial attitude and attitude to take risk with an active personality.

\section{Conclusions}

The findings of this research indicate that there are five major factors that influence the social entrepreneurship intentions among university students such as social entrepreneurial interest, entrepreneurial attitude, proactive personality, entrepreneurship education, perceived behavioral control. Out of these first three factors were identified most important.

Social entrepreneurial interests showed a moderate relationship with proactive personality, entrepreneurial attitude, perceived behavioral control and entrepreneurship education. The study also identified three factors which constraints the intention of students towards starting of social entrepreneurship namely, fear of risk, lack of financial and moral support and lack of knowledge about social entrepreneurship. Out of that fear of risk was identified as the one of the main constraints for students.

These findings highlight the need to motivate and guide those students that have the desire to start their own businesses of a social nature. Based on the findings of this study, it is recommended that universities should guide students who aspire to be social entrepreneurs to realize their goal. Social entrepreneurship has proven to be a promising and important global phenomenon that certainly deserves rigorous academic attention. Increased levels of entrepreneurial activity, particularly social entrepreneurship, will help to eradicate high levels of unemployment and improve the lives of people in society.

The universities should involve in an early stage to provide entrepreneurship education on to increase awareness of students about entrepreneurship, shaping their attitude toward the behavior and enhancing their perceived behavioral control and personality traits. Universities shall organize more entrepreneurial-related activities or programs and workshops that will provide opportunities for students to involve in managing their own business and get prior business experience

The constraints that hinder their interest towards social entrepreneurship should be eliminated. The family, peers and teachers should encourage and motivate the students who comes up with innovative ideas and should provide support to those who really want to achieve their goals.

\section{References}

[1] Agarwal, K. K., \& Upadhyay, R. K. (2009). Attitude of Youth Towards Entrepreneurship: A Case Study of Varanasi. IUP Journal of Entrepreneurship Development, 6(2), 49. 
[2] Ahmed, I., Nawaz, M. M., Ahmad, Z., Shaukat, M. Z., Usman, A., Rehman, W. U., \& Ahmed, N. (2010). Determinants of students' entrepreneurial career intentions: Evidence from business graduates. European Journal of Social Sciences, 15(2), 14-22.

[3] Maalu, E. W. K. J. K. (2012). Perception of entrepreneurship as a career by students from selected public secondary schools in Nairobi. Perception, 2(3), 101-120.

[4] Lorz, M. (2011). The impact of entrepreneurship education on entrepreneurial intention (Doctoral dissertation, University of St. Gallen).

[5] Müller, S., \& Neck, H. (2010, January). Generation impact: Student preferences to start social or traditional ventures. In United States Association for Small Business and Entrepreneurship. Conference Proceedings (p. 157). United States Association for Small Business and Entrepreneurship.

[6] Nga, J. K. H., \& Shamuganathan, G. (2010). The influence of personality traits and demographic factors on social entrepreneurship start up intentions. Journal of business ethics, 95(2), 259-282.

[7] Nian, T. Y., Bakar, R., \& Islam, M. (2014). Students' Perception on Entrepreneurship Education: The Case of Universiti Malaysia Perlis. International Education Studies, 7(10), 40-49.

[8] Salamzadeh, A., Azimi, M. A., \& Kirby, D. A. (2013). Social entrepreneurship education in higher education: insights from a developing country. International Journal of Entrepreneurship and Small Business, 20(1), 17-34.

[9] Tiwari, P., Bhat, A. K., \& Tikoria, J. (2017). Predictors of social entrepreneurial intention: an empirical study. South Asian Journal of Business Studies, 6(1), 53-79.

[10] Shane, S., \& Venkataraman, S. (2000). The promise of entrepreneurship as a field of research. Academy of Management Review, 25(1), 217-226.

*Corresponding author.

E-mail address: csarada59@gmail.com 